\title{
Performance of steel-making slag concrete reinforced with fibers
}

\author{
Vanesa Ortega-López ${ }^{1,{ }^{*},}$, José Antonio Fuente-Alonso ${ }^{2}$, Marta Skaf $^{2}$, Amaia Santamaría ${ }^{3}$, \\ Ángel Aragón ${ }^{1}$, and Juan Manuel Manso ${ }^{1}$ \\ ${ }^{1}$ Department of Civil Engineering/University of Burgos. C/Villadiego s/n. 09001 Burgos, Spain. \\ ${ }^{2}$ Department of Construction/University of Burgos. C/Villadiego s/n. 09001 Burgos, Spain. \\ ${ }^{3}$ Department of Mining and Metallurgical Engineering/University of Basque Country. Alameda \\ Urquijo s/n. 48013 Bilbao, Spain.
}

\begin{abstract}
In this research, the possibility of making concrete reinforced with fibers and manufactured with recycled aggregates from carbon steel production was explored. Electric arc furnace slag (EAFS) was used as coarse and medium aggregate, and part of the sand sizes. Metallic and synthetic fibers were added in different amounts. Initially, the properties of EAFS and their suitability to be used in the manufacture fiber reinforced concrete were analysed. Then, a series of fiber reinforced concrete mixtures were developed incorporating EAFS, and they were compared with the reference mixtures, made with conventional components plus fibers and made with EAFS without fibers. A series of tests were performed, including concepts such as consistency, compressive strength, flexural strength, splitting tensile strength, resistance to water penetration or toughness. The results show that it is possible to make a suitable steel-slag concrete reinforced with fibers, complying with the standard requirements for it use in pavements and slab, and improving their proprieties respect to the control mixtures.
\end{abstract}

\section{Introduction}

Electric Arc Furnace Slag (EAFS) is a by-product of the steel electric industry, produced following the melting of scrap steel. It is usually presented as gravel sized aggregate.

In Spain, approximately $70 \%$ per cent of total steel production (14 millions of tons) is from steel electric furnaces, together with $1 \mathrm{MT}$ of EAFS [1].

The steelmaking industry is mainly concentrated in the north of Spain. Therefore, it is so important for us to reuse this by-product in order to reduce slags landfilling and contribute to global sustainability.

In general, steelmaking slags are products which have certain risk of expansion, mainly due to a potential presence of free lime and periclase. So, an outdoor weathering and some additional cautions are necessary to prevent the occurrence of any expansive phenomena [2-

\footnotetext{
* Corresponding author: vortega@ubu.es
} 
6]. In the last decades, important works on EAFS [7-10] and LFS characterization [11-13] have been published; it has been demonstrated the suitability of both slags in different applications, such as bituminous mixtures [14-18], concrete and mortars [19-34], selfcompacting concrete [35-37], making clinker [38], soil stabilization [39-41] and others [42, 43]. Despite these recycling possibilities, in Spain, approximately $23 \%$ of the electric slag is accumulated in landfill sites.

On the other hand, the construction sector is an important consumer of natural aggregates. Total consumption of natural aggregates in Spain is around 90 MT per year, resulting in a consumption of natural resources and exploitation of quarries.

With this work, we tried to convert the EAFS in steel aggregate for manufacturing steelslag concrete.

The aim of the research carried out to outline this paper, was based on the reuse of EAF slags in the construction of concrete pavements and concrete slabs reinforced with fibers, in order to avoid the spread of the superficial cracks during the initial drying of the concrete, to improve its flexural and splitting tensile strength and to increase its capacity to absorb rupture energy.

For that, the slag was used as coarse and medium aggregate in the concrete mixture, and the sizes of sand were completed with $50 \%$ of slag and $50 \%$ of siliceous sand; which is mean approximately $75 \%$ of EAFS and $25 \%$ of natural aggregate in the finale concrete mixture. The siliceous sand, with rounded morphology, counteracted the effect of the surface irregularity of the EAFS, improving the fluidity throughout the concrete mass [44]. Furthermore, different dosages and types of fibers (metallic and synthetic) were studied in order to determine which are the most suitable for the aim proposed.

\section{Materials}

The following materials were used in this research:

- Ordinary Portland Cement (OPC) CEM I 42,5R.

- Water from an urban water supply

- Natural siliceous aggregates: It has been provided in three granulometric sizes: 0/4, 4/12 and $12 / 25 \mathrm{~mm}$; the size limestone aggregate employed in the EAFS concrete was the sand $0 / 4 \mathrm{~mm}$, with fine content according with UNE-EN-933-1 of $[45,46] 1.58 \%$ and sand equivalent according with UNE-EN 933-8 of 89 .

- Superplasticizers: Policarboxilato modified with water. Density of $1.08 \mathrm{~g} / \mathrm{cm} 3, \mathrm{pH}$ of 5 and solid content of $36 \%$.

- EAFS aggregates: It has been provided in three granulometric sizes: 0/4, 4/10 and 10/20 $\mathrm{mm}$ (Figure 1). The lack of fines is appreciated on the sand slag. EAFS is heavy, with density over $3500 \mathrm{~kg} / \mathrm{m}^{3}$ and a very resistant aggregate (loss Angeles Loss: 24\%, Flakiness index: $3 \%$ ). The main compounds of the EAFS are shown in Table 1.

- Metallic fibers (RL-45/50-BN): hard drawn steel filaments with formed ends to improve adhesion; Synthetic fibers (M-48): polyolefins curly monofilament (Figure 2).

Table 1. Main chemical composition of the EAFS.

\begin{tabular}{|c|c|c|c|c|c|c|}
\hline Component & $\mathrm{CaO}$ & $\mathrm{SiO} 2$ & $\mathrm{MgO}$ & $\mathrm{Al}_{2} \mathrm{O}_{3}$ & $\mathrm{Fe}_{2} \mathrm{O}_{3}$ & $\mathrm{MnO}$ \\
\hline EAFS wt.-\% & 27.7 & 19.1 & 2.5 & 13.7 & 26.8 & 5.3 \\
\hline
\end{tabular}



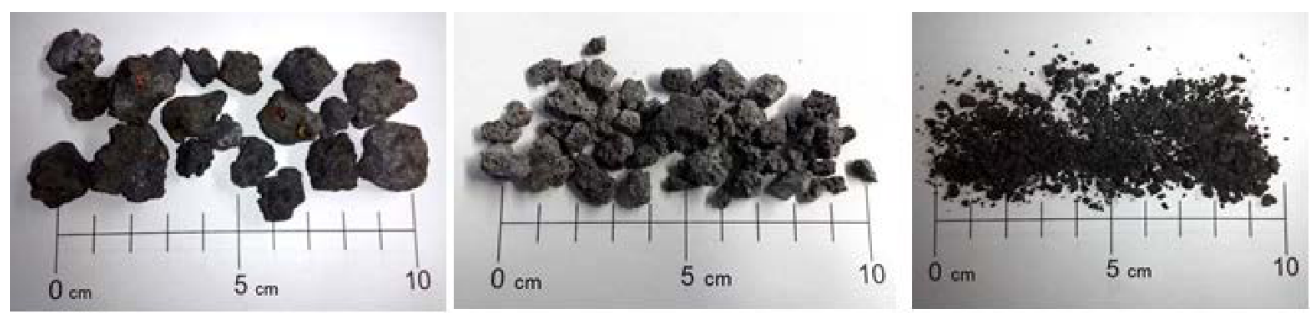

Fig. 1. EAFS granulometric sizes.

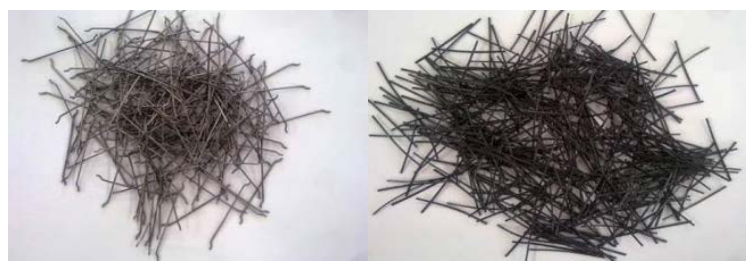

Fig. 2. Metallic and Synthetic fibers.

\section{Mix design}

Some dosages were used for the reference mixtures, which had previously been endorsed by other authors in bibliography:

- Reference mixture $\mathbf{P}$, was a mixture with natural aggregates and $30 \mathrm{~kg}$ of metallic fibers per $\mathrm{m}^{3}$ of concrete, according with Turmo et al [47].

- Reference mixture $\mathbf{E}$, was a mixture with $75 \%$ of EAFS aggregates and $25 \%$ of siliceous sand without fibers, according with Manso et al [30].

Other mixes under study in this research (EM1, EM2, ES1, ES2) had the same dosage as the reference mix E, but including two types of fiber reinforcements (metallic and synthetic) in different quantities, within the range of $0.4-0.6 \%$ of fibers by unitary volume of concrete. Table 2 shows the compositions of the mixes under study.

For all mixtures, the following parameters were constant: amount of cement: $363 \mathrm{~kg} / \mathrm{m}^{3}$; relation water/cement (w/c): 0.5 ; relation coarse aggregate/fine aggregate/cement: 3/3/1.

Table 2. Mix proportioning of components in manufactured concretes.

\begin{tabular}{l|rrrrrrr}
\hline \multicolumn{2}{l|}{$\begin{array}{l}\text { Mix design }\left(\mathrm{kg} / \mathrm{m}^{3}\right) \\
\text { Cement }\end{array}$} & P & E & EM1 & EM2 & ES1 & ES2 \\
Water & 180 & 360 & 360 & 360 & 360 & 360 \\
\hline \multirow{5}{*}{ Siliceous aggregates } & Size 0/4 mm & 800 & 500 & 500 & 500 & 500 & 500 \\
& Size 4/12 mm & 575 & - & - & - & - & - \\
& Size $12 / 20$ & 465 & - & - & - & - & - \\
& mm & & & & & & \\
\hline \multirow{5}{*}{ EAFS aggregates } & Size 0/4 mm & - & 515 & 515 & 515 & 515 & 515 \\
& Size 4/10 mm & - & 670 & 670 & 670 & 670 & 670 \\
& Size 10/20 & - & 550 & 550 & 550 & 550 & 550 \\
Plasticizer (1-1.5\% wt. of cement) & 3.63 & 5.44 & 5.44 & 5.44 & 5.44 & 5.44 \\
Metallic Fibers & 30 & - & 30 & 45 & - & - \\
Synthetic Fibers & - & - & - & - & 3.5 & 5 \\
\hline
\end{tabular}




\section{Results and discussion}

\subsection{Consistency of freshly mixtures}

The consistency of freshly mixed concrete was measured with Abrams Cone, according to UNE 12350-2, before and after including the fibers. The results show that the mixture with natural aggregates and fibers had soft/plastic consistency and the rest of the mixtures manufactured with EAFS or EAFS plus metallic/synthetic fibers had dry consistency.

\subsection{Compressive strength}

The compressive strength was measured on cylindrical concrete specimen, with $150 \mathrm{~mm}$ of diameter and $300 \mathrm{~mm}$ of height, cured during 28 days in moist chamber at $20+/-2{ }^{\circ} \mathrm{C}$ and $95 \%$ of moisture. The assay was performed in triplicate. According to UNE 83507, the results obtained are shown in Table 3.

Results show higher compressive strength in the concretes with steel-slag aggregates than the concretes with natural aggregates, even when those contained reinforcing fibers. The mixture $\mathrm{E}$ (with EAFS without fibers) had an increase of $43 \%$ of compressive strength respect to the mixtures $\mathrm{P}$ (with natural aggregates and fibers).

EM2 and ES1 are the mixtures with better results in this test, with an increase of $10-12 \%$ of compressive strength with respect to the same concrete without fibers. These results are according with other authors who said that fiber volumes added to concrete mixes at $0.5 \%$, $1.0 \%$ and $1.5 \%$ by volume of concrete improve the compressive strength between $4 \%$ and $19 \%$ [48].

Table 3. Compressive strength, Flexural strength and Splitting tensile strength.

\begin{tabular}{|c|c|c|c|}
\hline Mixture & $\begin{array}{c}\text { Compressive } \\
\text { Strength } \\
\text { 28 days (MPa) }\end{array}$ & $\begin{array}{c}\text { Flexural } \\
\text { Strength } \\
\text { 28 days (MPa) }\end{array}$ & $\begin{array}{c}\text { Splitting } \\
\text { Tensile } \\
\text { Strength } \\
\text { 28 days (MPa) }\end{array}$ \\
\hline P & 46.30 & 5.15 & 4.33 \\
\hline E & 66.05 & 6.80 & 4.20 \\
\hline EM1 & 54.00 & 5.95 & 5.01 \\
\hline EM2 & 72.62 & 7.00 & 5.45 \\
\hline ES1 & 74.04 & 7.13 & 5.23 \\
\hline ES2 & 66.50 & 6.88 & 4.59 \\
\hline
\end{tabular}

\subsection{Flexural strength}

The flexural strength was measured on concrete specimen with dimensions 150x150x600 $\mathrm{mm}$ and 100x100x400 mm, cured in moist chamber during 28 days. According to the UNE 83509 , the load was applied in two spaced points between them $1 / 3$ of the length of the specimen (Figure 3 ). The results obtained are shown in Table 3.

All the steel-slag concretes had better results than the conventional one, even with fibers. The average of the flexural strength for steel-slag concretes with fibers had an increase upper than $30 \%$ respect to the reference mixture $P$.

It was well known that the steel-slag concrete improves the flexural strength [6] and that the fibers provide better deformation performance by flexion [49] according to the results obtained for concrete manufactured with EAFS and fibers. 
The results were similar to the previous ones of compressive strength, reaching the best results the mixtures EM2 and ES1.
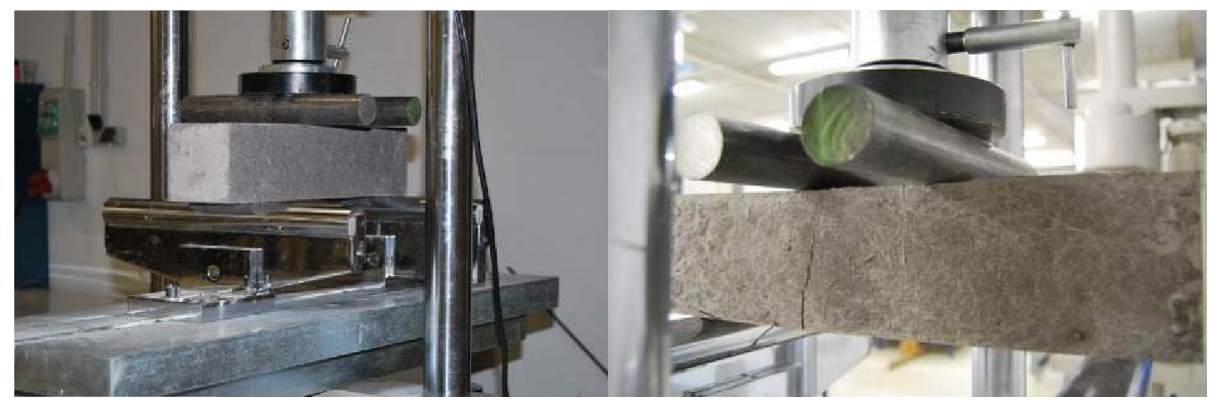

Fig. 3. Flexural strength test.

\subsection{Splitting tensile strength}

The splitting tensile strength was measured on cylindrical concrete specimen with diameter of $150 \mathrm{~mm}$ and height of $300 \mathrm{~mm}$, cured in moist chamber during 28 days. According to the UNE 12390-6, the load was applied over two opposite lines until failure. The results provide the maximum load that the pavement is able to support (Figure 4). The results obtained were also shown in Table 3.

All the mixtures with fibers had better performance at splitting tensile strength than the mixture E (without fibers), especially the mixtures with EAFS and fibers, EM2 and ES1. It is possible that higher amount of synthetic fibers in mixture ES2 than in mixture ES1 damages the strength characteristics of the hardened concrete, well by its problematic mix process or by the low hydration of the concrete components.

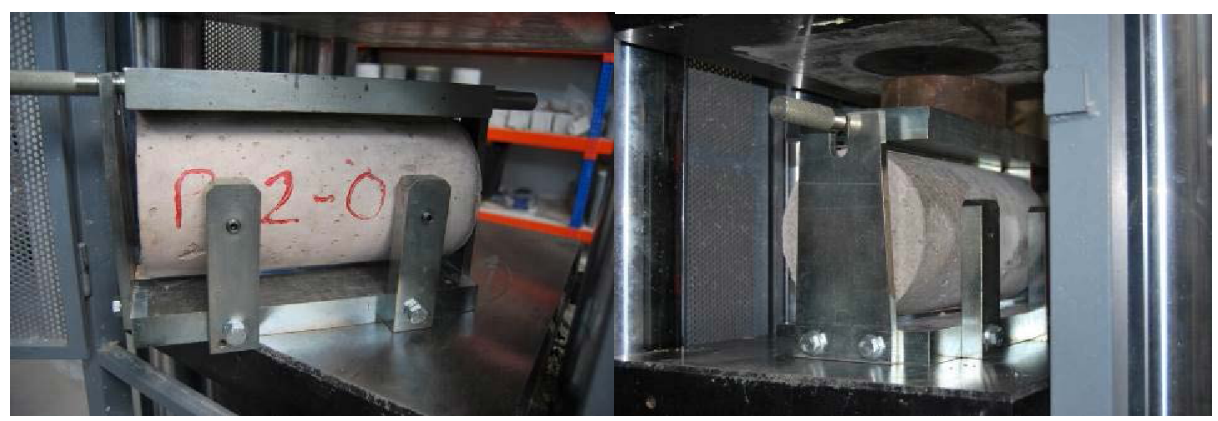

Fig. 4. Splitting tensile strength test

\subsection{Resistance to water penetration}

The resistance to water penetration under pressure was measured on cylindrical concrete specimen with diameter of $150 \mathrm{~mm}$ and height of $300 \mathrm{~mm}$, cured in moist chamber during 28 days. According to the UNE EN 12390-8, the water was applied under pressure of 500+/$50 \mathrm{kPa}$ during 72 hours in one of the specimen faces. After that, the specimen was broken and the depth of water penetration was measured. The results of the maximum depth of water penetration are shown in Figure 5.

All the mixtures with EAFS had better resistance to water penetration than the conventional concrete with natural aggregates. However, in this test, the fibers in the 
concretes manufactured with EAFS did not improve the results respect to concrete without them.

Even so, all the mixtures fulfilled the requirements of the EHE standard [50], which specifies, for the worst environmental exposure, the value of maximum depth of water penetration under $30 \mathrm{~mm}$. Therefore, these concretes were considered impermeable enough for its use in pavements.

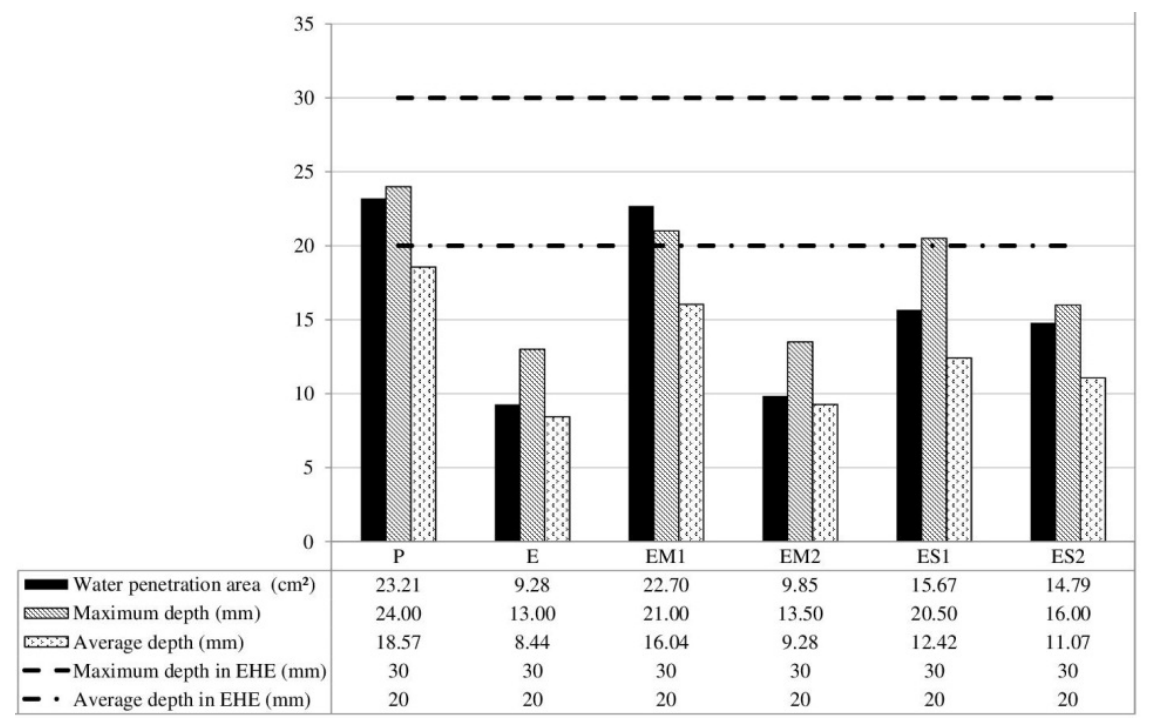

Fig. 5. Depth of water penetration under pressure.

\subsection{Toughness by compression}

The toughness is the energy required for a prespecified total deterioration or breakage of the material. It is one of the most important characteristics that the fibers provide to the material.

The toughness by compression was measured on cylindrical concrete specimen with diameter of $150 \mathrm{~mm}$ and height of $300 \mathrm{~mm}$. According to the UNE 83508, the results provide the area bounded by the load-deformation curve from the origin 0 , and the ordinate corresponding to a deformation of $1.125 \mathrm{~mm}$.

The mixture EM2 (toughness of 1949300 N.mm) had better results than the mixture ES1 (toughness of 1887900 N.mm), which means that metallic fibers provided greater postcracking strength and higher increase of concrete ductility.

\subsection{Impact strength}

Another important characteristic that the fibers bring to the concrete, once again directly related with toughness, is increased concrete strength against impacts, collapse, and other dynamic loading. A drop weight impact test was applied to cylindrical concrete specimens, in accordance with the UNE 83514 [45] standard. The test results, shown in Table 4, record the number of hits until the first crack appears and the number of hits up until breakage of the specimen.

In view of test results, the fiber-reinforced concretes (i.e EM2, ES1, P) clearly appear to have much better impact strength than the equivalent not-reinforced concrete $(\mathrm{E}, \mathrm{P}$ without fibers), both against the first signs of cracking and especially against breakage. Additionally, the concrete mixes with electric arc furnace slag (i.e E, EM2, ES1) showed 
better impact strength than the corresponding mixes made with conventional aggregates $(\mathrm{P}$ not fibers, P).

Table 4. Impact and abrasion resistance.

\begin{tabular}{llccccc}
\hline Property & & E & EM2 & ES1 & P & $P_{\text {not fibers }}$ \\
\hline Impact & Number of hits until first crack & 11 & 46 & 24 & 19 & 6 \\
Strength & Number of hits until breakage & 13 & 155 & 88 & 50 & 8 \\
\hline
\end{tabular}

\section{Conclusions}

The conclusions from this work can be summarized as follows:

- Steel-slag concretes reinforced with fibers, metallic or synthetic, at around 0.4$0.6 \%$ by volume of concrete, provided concretes with suitable mechanical behavior.

- The mixture reinforced with metallic fibers provided slightly better results of Toughness and Impact Strength than the concrete reinforced with synthetic fibers.

- Due to the poor workability and docility of the fiber reinforced concretes manufactured with EAFS, it is recommended a water/cement ratio over 0.5 and the use of plasticizer additive, as well as the incorporation of siliceous sand in order to compensate the lack of fines of the EAFS.

The authors wish to express their gratitude to the Junta de Castilla y León (Regional Government), to the Spanish Ministry (MINECO) for FEDER Funds through project BIA2014-55576-C2-1-R, which contribute to financing this research work. It could be not have gone ahead without the materials supplied by Hormor-Zestoa, Syka admixtures and beaker and Cementos Alfa.

\section{References}

1. Steel Statistical Yearbook : World Steel Association (2014).

2. Wang, G., Y. Wang, and Z. Gao, Use of steel slag as a granular material: volume expansion prediction and usability criteria. Journal of Hazardous Materials, 184 p. $555-$ 560 (2010).

3. Pellegrino, C., et al., Properties of concretes with black/oxidizing electric arc furnace slag aggregate. Cement and Concrete Composites, 37(1): p. 232-240 (2013).

4. Juckes, L.M., The volume stability of modern steelmaking slags. Transactions of the Institution of Mining and Metallurgy, Section C: Mineral Processing and Extractive Metallurgy, 112(3 DEC.): p. 177-197 (2003).

5. Goldring, D.C. and L.M. Juckes, Petrology and stability of steel slags. Ironmaking and Steelmaking, 24(6): p. 447-456 (1997).

6. Manso, J.M., J.J. Gonzalez, and J.A. Polanco, Electric arc furnace slag in concrete. Journal of Materials in Civil Engineering, 16(6): p. 639-645 (2004).

7. López, F.A., A. López-Delgado, and N. Balcázar, Physico-chemical and mineralogical properties of EAF and AOD Slags. Afinidad, 53(461): p. 39-46 (1996).

8. Luxán, M.P., et al., Characteristics of the slags produced in the fusion of scrap steel by EAF. Cement and concrete Research, 30(4): p. 517-519 (2000).

9. Vazquez Ramonich, E. and M. Barra, Reactivity and expansion of electric arc furnace slag in their application in construction. Materiales de Construcción, 51(263-264): p. 137-148 (2001).

10. Frías Rojas, M., M.I. Sánchez, and A. Uria, Study of the inestability of black slags from EAF steel industry. Materiales de Construcción, 52(267): p. 79-83 (2002). 
11. Shi, C., Characteristics and cementitious properties of ladle slag fines from steel production. Cement and concrete Research, 2002. 32(3): p. 459-462 (2002).

12. Posch, W., H. Presslinger, and H. Hiebler, Mineralogical evaluation of ladle slags at voestalpine stahl GmbH. Ironmaking and Steelmaking, 29(4): p. 308-312.

13. Setién, J., D. Hernández, and J.J. González, Characterization of ladle furnace basic slag for use as a construction material. Construction and Building Materials, 23(5): p. 17881794 (2009).

14. Pasetto, M. and N. Baldo, Mix design and performance analysis of asphalt concretes with electric arc furnace slag. Construction and Building Materials, 25(8): p. 3458-3468 (2011).

15. San José, J.T. and A. Uría, Escorias de horno de arco eléctrico en mezclas bituminosas. Arte y Cemento, 1905: p. 122-125 (2001).

16. Skaf, M., et al., Ladle furnace slag in asphalt mixes. Construction and Building Materials, 122: p. 488-495 (2016).

17. Pasetto, M. and N. Baldo, Fatigue performance of asphalt concretes made with steel slags and modified bituminous binders. International Journal of Pavement Research and Technology, 6(4): p. 294-303 (2013).

18. Pasetto, M. and N. Baldo. Resistance to permanent deformation of base courses asphalt concretes made with RAP aggregate and steel slag. in 12th International Conference on Asphalt Pavements, ISAP 2014. Raleigh, NC: Taylor and Francis - Balkema (2014).

19. Manso, J.M., et al., Ladle Furnace Slag in Construction. J Mater Civil Eng., 17: p. 513518 (2005).

20. Bosela, P., et al., Fresh and hardened properties of paving concrete with steel slag aggregate. Propiedades para firmes del hormigón fabricado con áridos siderúrgicos. Carreteras: Revista técnica de la Asociación Española de la Carretera, 4(166): p. 55-66 (2009).

21. Abu-Eishah, S.I., A.S. El-Dieb, and M.S. Bedir, Performance of concrete mixtures made with electric arc furnace (EAF) steel slag aggregate produced in the Arabian Gulf region. Construct Build Mater, 34: p. 249-256 (2012).

22. Kim, S.W., Y.J. Lee, and K.H. Kim, Bond behavior of RC beams with electric arc furnace oxidizing slag aggregates. J Asian Architect Build Eng., 11(2): p. 359-366 (2012).

23. Pellegrino, C. and F. Faleschini, Experimental behavior of reinforced concrete beams with electric arc furnace slag as recycled aggregate. ACI Materials Journal, 110(2): p. 197-205 (2013).

24. Anastasiou, E., K. Georgiadis Filikas, and M. Stefanidou, Utilization of fine recycled aggregates in concrete with fly ash and steel slag. Constr Build Mater, 50: p. 154-161 (2014).

25. Manso, J.M. and J. Setién, Investigación de nuevos usos de las escorias de horno eléctrico de arco (EAF): la oportunidad de los hormigones. Hormigón y Acero, 241: p. 51-57 (2006).

26. Santamaría, A., et al., The use of steelmaking slags and fly ash in structural mortars. Construction and Building Materials, 106: p. 364-373 (2016).

27. Arribas, I., et al., Electric arc furnace slag and its use in hydraulic concrete. Construction and Building Materials, 90: p. 68-79 (2015).

28. Arribas, I., et al. Application of steel slag concrete in the foundation slab and basement wall of the Tecnalia kubik building. in 6th European Slag Conference Proceedings. Madrid, Euroslag (2010).

29. Etxeberria, M., et al., Properties of concrete using metallurgical industrial by-products as aggregates. Construction and Building Materials. 24(9): p. 1594-1600 (2010).

30. Manso, J.M., et al., Design and elaboration of concrete mixtures using steelmaking slags. ACI Materials Journal, 108(6): p. 673-681 (2011). 
31. Papayianni, I. and E. Anastasiou, Concrete incorporating highcalcium fly ash and EAF slag aggregates. Magazine of Concrete Research, 63(8): p. 597-604 (2011).

32. Polanco, J.A., et al., Strength and durability of concrete made with electric steelmaking slag. ACI Materials Journal, 108(2): p. 196-203 (2011).

33. San-José, J.T., et al., The performance of steel-making slag concretes in the hardened state. Materials and Design, 60: p. 612-619 (2014).

34. Arribas, I., et al., Durability studies on steelmaking slag concretes. Materials and Design, 63: p. 168-176 (2014).

35. Anastasiou, E.K., I. Papayianni, and M. Papachristoforou, Behavior of self compacting concrete containing ladle furnace slag and steel fiber reinforcement. Materials and Design, 59: p. 454-460 (2014).

36. Tomasiello, S. and M. Felitti, EAF slag in self-compacting concretes. Facta universitatis - series: Architecture and Civil Engineering, 8(1): p. 13-21 (2010).

37. Santamaría, A., et al., Self-compactin concrete incorporating electric arc-furnace steelmaking slag as aggregate. Materials and Design, 115: p. 179-193 (2017).

38. Akin Altun, I. and I. Yilmaz, Study on steel furnace slags with high $\mathrm{MgO}$ as additive in Portland cement. Cement and Concrete Research, 32(8): p. 1247-1249 (2002).

39. Ortega-López, V., et al., The long-term accelerated expansion of various ladle-furnace basic slags and their soil-stabilization applications. Construction and Building Materials, 68: p. 455-464 (2014).

40. Manso, J.M., et al., The use of ladle furnace slag in soil stabilization. Construction and Building Materials, 40: p. 126-134 (2013).

41. Montenegro, J., et al., Ladle furnace slag in the construction of embankments: expansive behavior. J Mater Civil Eng., 25(8): p. 972-979 (2013).

42. Bäverman, C., et al., Serial batch test performed on municipal solid waste incineration bottom ash and electric arc furnace slag, in combination with computer modelling. Waste management and Research, 15(1): p. 55-71 (1997).

43. Sasamoto, H., et al., Development of fishing block using EAF refining slag. Tetsu-ToHagane/Journal of the Iron and Steel Institute of Japan, 89(4): p. 461-465 (2003).

44. Pellegrino, C. and V. Gaddo, Mechanical and durability characteristics of concrete containing EAF slag as aggregate. Cement and Concrete Composites, 31(9): p. 663-671 (2009).

45. EN Euronorm. European Committee for Standardization: Rue de Stassart, 36. Belgium1050 Brussels.

46. CEN. European Committee for Standardization. rue de Stassart, 36. Brussels B-1050.

47. Turmo, J., et al., Study of the shear behaviour of fiber reinforced concrete beams. Materiales de Construcción, 58(292): p. 5-13 (2008).

48. Yazici, S., G. Inan, and V. Tabak, Effect of aspect ratio and volume fraction of steel fiber on the mechanical properties of SFRC. Construction and Building Materials, 21(6): p. 1250-1253 (2007).

49. Bemal, S., et al., Mechanical behaviour of steel fibre-reinforced alkali activated slag concrete. Materiales de Construccion, 59(293): p. 53-62 (2009).

50. Instrucción para realización de obras de hormigón estructural, M.d. Fomento, Editor., Comisión Permanente de Hormigón: Madrid (2008). 